\title{
Genotipo ir fenotipo sąsajos, sergant paveldima Lèberio optine neuropatija
}

\section{Matukynaité* \\ R. Liutkevičiené ${ }^{* *}$ \\ A. Gelžinis*** \\ R. Žemaitiené $\dot{x}^{* * *}$}

*Lietuvos sveikatos mokslu universitetas, Medicinos akademija

**Akių ligu klinika, Neuromokslu institutas, Lietuvos sveikatos

mokslu universitetas;

Neuromokslu institutas, Lietuvos

sveikatos mokslu universitetas

***Akiu ligu klinika, Neuromoksly institutas, Lietuvos sveikatos

mokslu universitetas

\begin{abstract}
Santrauka. Paveldima Lèberio optinė neuropatija (PLON) - viena dažniausių paveldimų mitochondrinių optinių neuropatijų, pasireiškianti abipusiu, beskausmiu, poūmiu ar ūminiu centrinio regejjimo praradimu. Liga dažniausiai pasireiškia 15-35 metų žmonėms. Didžioji dalis sergančiujų yra vyrai (apie $90 \%$ ). PLON pasireiškimas paprastai siejamas su trimis dažniausiai pasitaikančiomis taškinemmis mutacijomis mitochondrinejje deoksiribonukleorūgštyje (mtDNR): m.11778G $>$ A, m.14484T >C, m.3460G >A. Taškinės deoksiribonukleorūgšties mutacijos sąlygoja kvėpavimo grandinės I komplekso pažeidimą mitochondrijose visų pagrindinių žinomų mutacijų atvejais.

Šiame straipsnyje apžvelgiame PLON genotipo ir fenotipo sąsajas, esant įvairioms mtDNR mutacijoms, sergant PLON.
\end{abstract}

Raktažodžiai: paveldima Lèberio optinė neuropatija, genotipas, fenotipas, sąsajos.

\section{IVADAS}

Paveldima Lèberio optinė neuropatija (PLON) - viena dažniausiai pasitaikančiu mitochondrinių optinių neuropatijų. PLON paplitimas siejamas su m.11778G $>$ A, m.14484T $>C$, m.3460G $>$ A taškinèmis mutacijomis [1]. Liga ịprastai pasireiškia abipusiu, beskausmiu, poūmiu ar ūminiu centrinio regèjimo praradimu. Literatūroje aprašoma vis daugiau atvejų, kai daliai PLON sergančiu pacientų stebima ne tik ịprasta klinika, bet ir mitochondrinès encefalomiopatijos, laktatinès acidozès ir insultą primenančiu epizodu (angl. Mitochondrial Encephalomyopathy, Lactic Acidosis, and Stroke-like episodes, MELAS), Leigh, Harding ir kitų sindromų klinikinès išraiškos. Todèl vis dau-

\footnotetext{
Adresas:

Lina Matukynaite

Lietuvos sveikatos mokslu universitetas

Eiveniu g. 2, Kaunas

El.paštas l.matukynaite@gmail.com
}

giau tyrinejjamos genotipo ir fenotipo sąsajos, sergant PLON.

Šiame straipsnyje aptariame PLON klinikinius simptomus ir klinikines išraiškas, nulemtas skirtingų mutacijų.

\section{PLON BENDRI KLINIKINIAI SIMPTOMAI}

PLON būdingas gana greitas, neskausmingas, abipusis centrinio regejjimo praradimas (1 lentelè). Ligos simptomai dažniausiai pasireiškia jauniems vyrams (tik 10-20 \% nustatoma moterims) nuo 15 iki 35 metų amžiaus [2]. Tačiau yra aprašyta atvejų, kai liga diagnozuota 5-87 metų asmenims [3, 4]. Dèl šios ligos jauni žmonès per kelis mėnesius tampa silpnaregiais. Regos praradimas dažniausiai yra negrịžtamas procesas, tačiau kartais ir po kelerių metu galimas spontaninis regos atsistatymas, tai priklauso nuo mutacijos tipo ir paciento amžiaus, kuriame pasireiške ligos simptomai [1]. Maždaug $75 \%$ atvejų regos aštrumo sumažějimas ir centrinio regèjimo praradimas pasireiškia vienoje akyje, o po 8-12 savaičiu - ir kitoje [5, 6]. Vienpu-

(C) Neurologijos seminarai, 2020. Open Access. This article is distributed under the terms of the Creative Commons Attribution 4.0 International License CC-BY 4.0 (http://creativecommons.org/licenses/by/4.0/), which permits unrestricted use, distribution, and reproduction in any medium, provided you give appropriate credit to the original author(s) and the source, provide a link to the Creative Commons license, and indicate if changes were made. 
sis regos nervo pažeidimas, sergant PLON, yra labai retas. Akių dugno pakitimai priklauso nuo ligos stadijos [7]. Asimptomejje stadijoje pacientai skundų neturi, pirmasis ligos požymis - periferinė teleangiektazinė mikroangiopatija, taip pat optinès koherentinès tomografijos (OKT) tyrimo metu galima aptikti tinklainès nervinių skaidulu sluoksnio (TNSS) suplonejjimą apatiniame ir temporaliniame kvadrantuose [8], galimas sumažèjęs kontrastinis jautrumas, spalvų juslès ir erdvinio matymo sutrikimai [9]. Esant poūmei ligos stadijai (nuo ligos pradžios iki 6 mėnesių), stebimos peripapilinès teleangiektazinès kraujagyslès, peripapilinis TNSS paburkimas. Dinaminès stadijos metu (per 6-12 mènesių) TNSS peripapilinis paburkimas mažeja. Esant lėtinei stadijai (daugiau nei 12 mėnesių), OKT tyrimo metu dokumentuojamas peripapilinis TNSS išplonėjimas, ypač temporaliniuose kvadrantuose [10].

\section{MUTACIJOS}

Remiantis MitoMap duomenimis (http://www.mitomap.org/ MITOMAP), 19 mitochondrinès deoksiribonukleorūgšties (mtDNR) mutacijų yra siejamos su PLON pasireiškimu ir dar 18 mutacijų yra genų „kandidatų“ sąraše. Taip pat nemažai mutacijų yra galimai patogeninės. Jos nėra įtrauktos i oficialius sąrašus, nes nėra pakankamos tiriamųjų imties patogeniškumui nustatyti. Šiuo metu žinomos trys pagrindinès mutacijos, kurių mtDNR patogenetiniai variantai sudaro 90-95\% visų atvejų:

- m.3460G >A, esanti MT-ND1 gene,

- m.11778G >A, esanti $M T-N D 4$ gene,

- m.14484T>C, esanti MT-ND6 gene.

Jos visos lokalizuotos regionuose, koduojančiuose adenozintrifosfato (ATF) kvèpavimo grandinès I kompleksą [11]. Priklausomai nuo mutacijos, gali skirtis klinikinè eiga ir ligos prognozė [12].

\section{GENOTIPO IR FENOTIPO KORELIACIJA}

\section{m.11778G $>$ A}

MT-ND4 m.11778G>A mtDNR mutacija yra dažniausia iš sukeliančių PLON, ji nustatoma 50-70 \% visų atvejų [1]. Pacientams, turintiems šią mutaciją, ligos pradžia būna ūmesnè, o klinikinė ligos išraiška - sunkesnè, taip pat rečiau pasireiškia spontaninis regos aštrumo pagerẻjimas (apie 4-22\%), lyginant su pacientais, kuriems nustatyta m.14484T $>$ C mutacija [1, 13]. Nustatyta, kad m.11778G $>$ A mutacijos pasireiškimo santykis tarp vyrų ir moterų yra 4:1 [14], o regos funkcijos sutrikimas pasireiškia 19,4 metų amžiuje [15]. MitoMap patvirtintų mutacijų duomenimis, m.11778G $>$ A mutacija sukelia ne tik PLON, bet ir progresuojančią distoniją (angl. Leber's hereditary optic neuropathy and dystonia, LDYT) bei generalizuotą distoniją.
1 lentelè. Pagrindiniai PLON klinikiniai simptomai

\begin{tabular}{|l|l||}
\hline Požymis & Klinikiniai simptomai \\
\hline Klinika & $\begin{array}{l}\text { Poūmis, neskausmingas, abipusis centrinio regė- } \\
\text { jimo praradimas, sumažejęs kontrastinis jautru- } \\
\text { mas, spalvų juslės ir erdvinio matymo sutrikimai }\end{array}$ \\
\hline Ligos eiga & $\begin{array}{l}\text { Pasireiškia vienoje akyje, o po 8-12 savaičių - } \\
\text { ir antroje. Galimas spontaninis dalinis regos } \\
\text { pagerejjimas. }\end{array}$ \\
\hline $\begin{array}{l}\text { Akių } \\
\text { dugno } \\
\text { pokyčiai }\end{array}$ & $\begin{array}{l}\text { Kinta priklausomai nuo ligos stadijos: nuo } \\
\text { peripapilinio TNSS paburkimo ūmioje stadijoje } \\
\text { iki peripapilinio TNSS atrofijos temporaliniuose } \\
\text { kvadrantuose lètinejje stadijoje. }\end{array}$ \\
\hline $\begin{array}{l}\text { OKT } \\
\text { tyrimas }\end{array}$ & $\begin{array}{l}\text { OKT peripapiliniu TNSS išplonėjimas, ypač } \\
\text { temporalinėse srityse, vėliau atrofija pasireiškia } \\
\text { ir kituose kvadrantuose. }\end{array}$ \\
\hline \hline
\end{tabular}

Sąsajos tarp m.11778G > A mutacijos sukeltos PLON ir demielinizuojančio sindromo, kuris kliniškai ir radiologiškai yra tapatus išsètinei sklerozei (IS), buvo aprašytos jau 1992 m. ir pavadintos Harding sindromu (PLON-IS) [16]. Vèliau buvo nustatyta, kad ne tik ši, bet ir kitos dvi pagrindinès PLON sukeliančios mutacijos gali sukelti IS ar ị IS panašius simptomus [17]. Dažniausiai nustatoma m.11778G>A mutacija - 80,4 \%, o kitos dvi sutinkamos daug rečiau (m.3460G $>\mathrm{A}-10,7 \%, \mathrm{~m} .14484 \mathrm{~T}>\mathrm{C}-8,8 \%)$ [18]. Tikimybė susirgti Harding sindromu yra didesnè, nei PLON ir IS atskirai [19]. Sergant Harding sindromu, pirmiausia sutrinka regos aštrumas, o simptomai, rodantys IS, išsivysto vèliau. Harding sindromas skiriasi nuo klasikinès PLON: palyginus dažniau serga moterys $(2,1: 1)$, pacientai turi daugiau nei du pasikartojančius regos aštrumo praradimo epizodus ( $25 \%$ ) ar regejjimas sutrinka tik vienoje akyje $(8,5 \%)$, taip pat daug ilgesnis laiko intervalas, kai pažeidžiama antroji akis (vidutiniškai 1,66 metų, tačiau yra aprašyta atvejų, kai rega antraja akimi pablogèja po 17 metų). Kartu su abipuse regos nervų atrofija, šiems pacientams taip pat pasireiškia ir diseminuota centrinès nervų sistemos demielinizacija su būdingais baltosios medžiagos pažeidimo plotais [18].

Svarbu žinoti, kad pacientams, kuriems pasireiškia PLON, taip pat gali išsivystyti ir kita neurologinè simptomatika. Aprašyti atvejai, kai m.11778G $>$ A mutacija pasireiške ne tik regos aštrumo sutrikimu, bet ir ataksine eisena dẻl smegenėlių atrofijos, kardiomiopatija ir periferinėmis neuropatijomis [20], užpakalinès grižtamosios encefalopatijos sindromo požymiais [21], miokloniniais trūkčiojimais [22] ar psichomotorine regresija, refrakterine epilepsija ir progresuojančiais neurologiniais sutrikimais [23]. Literatūroje yra aprašytas atvejis, kai Perrault sindromas (PS) (tai retas, dažniau pasireiškiantis moterims, susirgimas, kuris paveldimas autosominiu recesyviniu būdu ir lemia kiaušidžių disgenezę, klausos bei neurologinius sutrikimus) pasireiškè drauge su PLON, esant m.11778G >A mutacijai, o kitų PS sukeliančių mutacijų nebuvo nustatyta. Kartu su PLON ir PS požymiais pasireiškė ataksija ir lengvas protinis atsilikimas [24]. 


\section{m.14484T $>$ C}

MT-ND6 m.14484T>C yra antra dažniausiai sukelianti PLON (15-30 \%) mtDNR mutacija. Ši mutacija taip pat pasižymi geriausiu regos aštrumo atsistatymo procentu 37-71\%, nepriklausomai nuo klinikinių simptomų ūmumo ligos pradžioje [1]. İdomu tai, kad klinikinių tyrimų metu buvo pastebėtas šios mutacijos paplitimas pagal regionus: daugiau kaip $86 \%$ prancūzų kanadiečių tautybės pacientų, sergančių PLON, turẻjo m.14484T >C mutaciją [25], o Suomijoje ir Olandijoje ši mutacija sutinkama ypač retai $-1: 40000$ ir rečiau [1]. m.11778G $>A$ ir m.14484T $>C$ mutacijos homoplazminèje būklèje dažnai nustatomos ir sveikoms moterims [26]. Tai leidžia daryti prielaidą apie mažą šios mutacijos skvarbą. Kituose moksliniuose tyrimuose nustatyta, kad m.14484T $>\mathrm{C}$ mutaciją turẻjusiems pacientams regos aštrumo pablogèjimas pasireiškè tik nuo 10 iki $60 \%$ [27-29]. Atliekant mitochondrijų visuminio genomo tyrimus, nustatyta, kad M9, M10 ir N9 haplogrupèse nustatyti mutacijų variantai: m.3394T>C $(M T-N D 1)$ [30], m.14502T>C $(M T-N D 4)$ ir m.14693A > G $(M T-T E)$, didina klinikinių požymių pasireiškimo dažnį [27], o m.10680G >A mutacija, būdama kartu su m.14484T $>C$ mutacija, lemia šimtaprocentį PLON pasireiškimą [31].

Nors MT-ND6 m.14484T>C mutacija, MitoMap patvirtintų mutacijų duomenimis, sukelia tik PLON, tačiau literatūroje galima rasti aprašytų atvejų, kai m.14484T >C mutacija sukelia ir neurologinę simptomatiką.

Paciento per didelis alkoholio ir cigarečių vartojimas, esant m.14484T>C mutacijai, lemia psichomotorinę regresiją ir pseudobradikineziją su difuzine smegenų atrofija, stuburo deformacijas ir ị metabolinị sindromą panašius pakitimus. Literatūroje yra aprašytas atvejis, kai m.14484T >C ir $12 S$ rRNA m.1555A $>$ G mutacijų buvimas kartu lèmė kurtumą [32]. Šie radiniai rodo, kad fenotipinis PLON spektras dèl m.14484T >C mutacijos gali būti platus ir galimai turètų būti siejamas su genetinių ir epigenetinių veiksnių sąveika [27].

\section{m.3460G $>$ A}

m.3460G > A mtDNR mutacija yra viena iš trijų dažniausiai PLON sukeliančių mutacijų ir sudaro 5-10 \% visų sergančiųjų. Iš trijų pagrindinių mutacijų, m.3460G >A mutacija pasireiškia sunkiausia klinikine eiga [12]. Tik $4 \%$ šios mutacijos nešiotojų regejjimas atsistato [1]. I ATF komplekso fermentiniai tyrimai atskleide, kad m.3460G $>$ A mutacija sumažino jo specifini aktyvumą $79 \%$, kai m.11778G > A mutacija sumažino tik $20 \%$, o m.14484T $>C$ mutacija išvis neturejo įtakos I ATF komplekso aktyvumui [33]. Atliekant tyrimus, buvo nustatytas m.3460G $>A$ PLON mutacijos specifinis biocheminis pasiskirstymas audiniuose: mitochondrijų funkcijos sutrikimas galvos smegenyse (pakaušio skiltyje), tačiau nepakitęs oksidacinis metabolizmas ekstraneuraliniame audinyje (griaučių raumenyse) [34]. MT-ND1 m.3460G >A mtDNR mutacija, MitoMap patvirtintų mutacijų duomenimis, sukelia tik PLON. Tačiau literatūroje aprašyti pavieniai atvejai, kai
m.3460G >A mutacijos sąlygota PLON pacientams pasireiškė kartu su torakaline kifoze ir klinikiniu neurologiniu sutrikimu, pavyzdžiui, posturaliniu ir rankų tremoru, parkinsonizmu kartu su distonija, periferine neuropatija, migrena ir epilepsija $[35,36]$.

\section{m.14459G $>$ A}

MT-ND6 m.14459G >A mutacija sutinkama retai, jos pasireiškimo dažnis nėra žinomas. MitoMap patvirtintų mutacijų duomenimis, ji sukelia PLON su distonija arba Leigh sindromą (LS). m.14459G > A heteroplazminè būklè labiau susijusi su PLON, o homoplazminè daugiau būdinga vaikams su distonija. Regos pažeidimas, esant m.14459G>A mutacijai, paprastai pasireiškia vėliau, o distonija išsivysto ankstyvoje vaikysteje [37]. Galimas ir PLON klinikinès išraiškos nebuvimas (aklumo / regos nervo atrofijos), kai stebimi tik distonijos požymiai [38]

Šios mutacijos fenotipas yra itin platus. Ligos pradžioje sergantysis gali būti vos 2 mėnesių amžiaus. Liga jam gali pasireiški kaip LS kartu su distonija ir turèti tokių papildomų simptomų, kaip psichomotorinis atsilikimas, distonija ir hipotonija [37], arba pasireikšti klinikiniais insulto epizodais be PLON požymių [39]. m.14459G >A mutacijos sąlygotos PLON galvos magnetinio rezonanso tomografijos (MRT) tyrime matomi būdingi aukšti T2 signalai lęšinio branduolio kiauto dalyje abipus [37]. Literatūroje aprašytas 3 metų mergaitès, turinčios šią mutaciją, klinikinis atvejis, kuriai pasireiškè anartrija (sunkesnè dizartrijos forma), distonija, spastiškumas ir švelni encefalopatija. MRT - tipiniai pokyčiai. Jos mamos pirmos eilès pusbroliui nustatyti nauji klinikiniai simptomai: šlubčiojimas ir švelni hemiparezė bei minėti pokyčiai, atlikus MRT [39]. Neurologiniai simptomai, primenantys Leigh sindromą, kurie komplikavosi PLON, buvo aprašyti trijų tarpusavyje nesusijusių vyrų klinikinių atvejų analizèje. Pacientai turèjo mtDNR mutacijas: $\mathrm{m} .3460 \mathrm{G}>\mathrm{A}, \mathrm{m} .14459 \mathrm{G}>\mathrm{A}$ ir m.14484T >C nukleotidų padètyse, atitinkamai. Stebint šių pacientų ị LS panašias encefalopatijas, atrodytų, kad šių mutacijų buvimas yra susijęs su daug sunkesnemis išeitimis, nei sergant tik izoliuota PLON [40].

\section{m.3376G $>$ A}

MT-ND1 m.3376G>A mutacija, MitoMap duomenimis, yra reta ir siejama su MELAS sindromu. Remiantis literatūros duomenimis, aprašytas vienas 20 metų amžiaus pacientès klinikinis atvejis, kuriai pasireiškè migrena su aura, traukuliai ir status epilepticus. Sulaukus 25 metų, pasireiškè širdies ir kvėpavimo funkcijų sutrikimas, manifestavo kairès pusès hemiparezè ir „tunelinis matymas“. Hemiparezė ėmė ryškiau progresuoti sulaukus 30 metų, kartu pasireiške koordinacijos sutrikimai ir ataksija. Ligai progresuojant, stebėti židininiai traukuliai ir migrenos epizodai, pacientei išsivystė kurtumas ir mioklonijos. Apie penkiasdešimtuosius gyvenimo metus regos aštrumas sumažejjo iki rankos judesių prieš aki [41]. Tačiau yra aprašyti ir atvejai, kai m.3376G > A kartu su c.4667A > T mutacija (kuri 
žinoma kaip sukelianti Joubert sindromą, kuriam būdinga smegenėlių pažaida) pasireiškè tik lengva fenotipine išraiška. Dviem negiminingiems vyrams nustatytos šios dvi heterozigotinès - c.4667A>T ir c.3376G >A mutacijos. Jiems liga pasireiškė okulomotorine apraksija ir nežymiu motorikos sutrikimu (jie pradèjo vaikščioti 18 ir 19 mėnesių amžiaus, ataksija nepasireiškè), nebuvo pažinimo funkcijos sutrikimų, o abiejų asmenų pirmos eilès giminaičiai buvo sveiki [42].

\section{m.10197G $>$ A}

MitoMap duomenimis, MT-ND3 m.10197G>A mutacija gali sukelti PLON, Leigh ligą, distoniją, insulto ar LDYT fenotipą. Nors mutacijos sukeliamų ligų sąrašas yra ilgas, dviejų ligų simptomų derinys, mūsų duomenimis, nèra aprašytas literatūroje. Aprašyti tik atskiri PLON ir LDYT atvejai. m.10197G>A mutacija gali sukelti tipinị PLON fenotipą tiek moterims, tiek vyrams, galimas ligos pasireiškimas ir vyresniame amžiuje [43, 44]. Taip pat galimas LDYT fenotipas, kurị sudaro PLON ir progresuojančios generalizuotos distonijos derinys [45].

\section{m.13094T $>$ C}

MT-ND5 m.13094T>C mutacija, MitoMap duomenimis, sukelia PLON, ataksiją su progresuojančios išorinès oftalmoplegijos (PEO) / MELAS / Leigh sindromais. Esant šiai mutacijai, gali pasireikšti labai įvairi neurologinė simptomatika, sunki ligos eiga ir ankstyva mirtis. Ištyrus 24 pacientus, kuriems buvo nustatyta ši mutacija, tik vienam pacientui kliniškai pasireiškė PLON. Dar vienam pacientui buvo nustatytas MELAS / PLON fenotipas, jam pasireiškė optinès neuropatijos simptomai kartu su traukuliais ir ic insultą panašiais epizodais (pažinimo funkcijų sutrikimu, ataksija ir periferine neuropatija) [46].

\section{m.3866T $>\mathrm{C}$}

MT-ND1 m.3866T>C geno mutacija apibūdinama kaip retas polimorfizmas. Hinttala R. ir bendraautoriai ištyrè penkias kartas (27 giminaičius iš motinos pusès). Tyrimų duomenimis, keturiems asmenims buvo nustatyta PLON, vienam - šlubavimas, o dar keturiems pasireiškė PLON kartu su šlubavimu. Atlikę šios šeimos mitochondrinès DNR genomo sekos analizę, mokslininkai nustatė m.3866T>C mutaciją, o ištyrus 135 kontrolinius asmenis - ši mutacija nebuvo rasta. m.3866T>C mutacija sumažina I ATF komplekso aktyvumą [47], sukeliantị mitochondrijų disfunkciją, susijusią su PLON pasireiškimu. Todèl m.3866T $>C$ mutacija siejama su PLON pasireiškimu kartu su šlubavimu [48]. m.3866T>C mutacija taip pat buvo nustatyta vaikui, turinčiam raumenų silpnumą, žemą ūgị, padidejusị laktato kieki kraujyje ir izoliuotą I ATF komplekso nepakankamumą raumenyse [47]. Taip pat aprašytas jaunos merginos atvejis, kai, turint šią mutaciją, stebėti tokie klinikiniai požymiai, kaip ịgimtas nistagmas, optinė neuropatija ir encefalomiopatija, kurie pasireiškè 4 metų amžiuje [49]. Yra duomenų, kad m.3866T >C mutacija yra būtina, tačiau jos vienos savaime nepakanka, kad būtų sukelta klinikine PLON išraiška, kaip tai vyksta esant: $\mathrm{m} .11778 \mathrm{G}>\mathrm{A}$, m.14484T $>$ C ir m.12338T $>$ C mutacijoms. Tačiau neabejojama, kad m.3866T >C mutacija turètų būti ịtraukta i PLON patogeninių mutacijų sąrašą [50].

\section{m.11253T $>$ C}

MT-ND4 gene m.11253T >C mutacija nustatoma retai, tačiau manoma, kad ji gali sukelti PLON. Aprašytas atvejis, kai pacientui, turinčiam vienintelę šią su PLON susijusią mutaciją, pasireiškẻ būdinga klinika, o vèliau - ir spontaniškas regos atsistatymas [51]. Ši mutacija taip pat siejama su Parkinsono ligos etiologija. Tyrimo metu iš atrinktų galimai patogeninių mutacijų buvo nustatyta, kad labiausiai tikètina, jog m.11253T>C mutacija turi didžiausią funkcinę reikšmę PLON vystymuisi [52].

\section{MUTACIJŲ SĄVEIKA}

Dvi PLON lemiančios mutacijos vienam pacientui - itin retas reiškinys, tačiau panašu, kad jų buvimas kartu nesukelia sunkesnès ligos fenotipinės išraiškos. Literatūros duomenimis, aprašyta šeima, turẻjusi m.11778G $>\mathrm{A}$ ir m.3460G >A mutacijas homoplazminèje būklëje, be jokių kitų klinikinių simptomų, išskyrus PLON. Du pacientai apako būdami 20 ir 33 metų atitinkamai, tačiau jiems nebuvo nustatyta jokios neurologinès simptomatikos, o dvi moterys buvo asimptomės mutacijų nešiotojos [53]. Sunkesnès fenotipinès išraiškos nebuvimas, esant dviem mutacijoms kartu, gali būti aiškinamas tuo, kad mutacijos sutrikdo tą pati procesą mitochondrijose, todèl suminis efektas nesidubliuoja [12, 54].

m.11778G $>A$ ir m.14484T $>$ C mutacijų kombinacija taip pat nelèmė sunkesnès fenotipinès išraiškos. Panašu, kad jų buvimas kartu tik didina tikimybę turèti klinikinę ligos išraišką. PLON plius fenotipas buvo nustatytas tik vienoje šeimoje, turinčioje abi - m.11778G $>$ A ir m.14484T $>C$ - mutacijas [12]. Moterims, turinčioms abi m.11778G $>$ A ir m. $14484 \mathrm{~T}>\mathrm{C}$ pirmines mutacijas, klinikiniai simptomai pasireiškè dažniau nei vyrams (3:1). Panašūs duomenys buvo aprašyti ir kituose moksliniuose tyrimuose, tačiau atsirado ir didesnị moterų sergamumą paneigiančių tyrimų. Dèl mažo pacientų skaičiaus sunku atlikti tyrimus ir pateikti patikimas išvadas [54]. Manoma, kad m.11696G > A mutacija gali veikti sinergistiškai su pagrindine PLON m.11778G>A mutacija ir sukelti didesnị regèjimo praradimo dažni, nei esant mutacijoms atskirai [54]. m.14502T >C, p.58I >V mutacija ND6 gene reikšmingai dažniau lemia didesnę fenotipinę išraišką, sergant pirmine PLON, sąlygota m.11778G>A mutacijos [55].

Iprastai m.3394T >C mutacija siejama su PLON, tačiau ji taip pat aprašyta ir kaip sukelianti cukrini diabetą, miopatijas, encefalomiopatijas, širdies aritmijas ir Fraser sindromą. Manoma, kad m.11778G >A ir m.3394T>C mutacijų kombinacija gali sukelti atipinę fenotipinę išraišką, sergant PLON. Aprašytas 37 metų vyro klinikinis atvejis, 
2 lentelè. Pagrindiniai PLON klinikiniai simptomai, priklausomai nuo mutacijos

\begin{tabular}{|c|c|c|}
\hline Mutacija & MitoMap patvirtintas fenotipas & Papildomos ypatybės \\
\hline $\mathrm{m} .11778 \mathrm{G}>\mathrm{A}$ & PLON, LDYT & $\begin{array}{l}\text { Ūmesnè eiga, sunkesnè klinikinè išraiška ir mažesnė } \\
\text { tikimybė spontaniniam regos pagerėjimui, lyginant su } \\
\text { m.14484T>C mutacija. Siejama su Harding sindromu } \\
\text { (PLON-IS). }\end{array}$ \\
\hline m.3460G $>A$ & PLON & $\begin{array}{l}\text { Sunkiausia iš trijų pagrindinių mutacijų, nes turi } \\
\text { mažiausią tikimybe spontaniniam regos atsistatymui, } \\
\text { stipriausiai sutrikdo I komplekso veiklą. }\end{array}$ \\
\hline $\mathrm{m} .14484 \mathrm{~T}>\mathrm{C}$ & PLON & $\begin{array}{l}\text { Mutacija pasižymi geriausiu dalinio regos pagerèjimo daž- } \\
\text { niu ir gana maža tikimybe turèti klinikinę ligos išraišką. }\end{array}$ \\
\hline $\mathrm{m} .14459 \mathrm{G}>\mathrm{A}$ & PLON su ar be distonijos, Leigh sindromas & $\begin{array}{l}\text { Heteroplazminė forma labiau susijusi su PLON, o } \\
\text { homoplazmine - su vaikams pasireiškiančia distonija. }\end{array}$ \\
\hline $\mathrm{m} .3376 \mathrm{G}>\mathrm{A}$ & Persidengiantis sindromas, apimantis PLON ir MELAS & - \\
\hline m.10197G >A & Leigh liga, distonija, insultas ar LDYT & \begin{tabular}{|l|} 
Šių skirtingų ligų simptomų derinio, aprašyto vienam \\
pacientui, literatūroje, mūsų duomenimis, nėra.
\end{tabular} \\
\hline $\mathrm{m} .13094 \mathrm{~T}>\mathrm{C}$ & $\begin{array}{l}\text { PLON, ataksija su PEO, MELAS, Leigh liga, } \\
\text { mioklonija, nuovargis }\end{array}$ & $\begin{array}{l}\text { Yra susijusi su sunkia ligos eiga ir ankstyvu } \\
\text { mirštamumu. }\end{array}$ \\
\hline m.3866T $>C$ & - (retas polimorfizmas) & Pasireiškia PLON su ar be šlubavimo. \\
\hline $\mathrm{m} .11253 \mathrm{~T}>\mathrm{C}$ & - (manoma, kad gali sukelti PLON) & $\begin{array}{l}\text { PLON būdinga klinikinè išraiška. Mutacija siejama su } \\
\text { Parkinsono ligos etiologija. }\end{array}$ \\
\hline
\end{tabular}

kai jam nuo 10 metų pasireiškė horizontalus žvilgsnio paralyžius, žvilgsnio sukeltas nistagmas, dizartrija ir smegenèlių ataksija. Smegenų ir akiduobès MRT tyrime - regos nervo ir smegenèlių atrofija, taip pat degeneraciniai pakitimai abiejuose apatiniuose alyvos branduoliuose [56].

\section{APTARIMAS}

Taigi PLON lemiančio genotipo klinikinè išraiška gali būti labai ịvairi - nuo besimptomės iki sunkios, kai stebimas ne tik regos aštrumo praradimas, bet ir MELAS, Leigh ar Harding sindromai kartu (2 lentelè). Klinikinejje praktikoje yra svarbu žinoti paciento genotipą, nes tai gali padèti nuspèti ligos išeitis ir galimus gretutinius susirgimus. Žinoma, PLON patogenezė vis dar nėra iki galo aiški, nes mtDNR mutacijos klinikinès išraiškos net toje pačioje šeimoje gali būti skirtingos. Tai patvirtina hipotezę, kad nukleariniai (branduoliniai) genai gali turèti įtakos modifikuojant mitochondrinių ligų klinikinę išraišką [38]. Taip pat manoma, kad tam didelị vaidmenị gali vaidinti epigenetiniai ir aplinkos veiksniai, kurie gali modifikuoti fenotipo pasireiškimą. Svarbu toliau tęsti tyrimus ir išsiaiškinti genotipo ir fenotipo koreliaciją bei tirti PLON patogenezini mechanizmą, kad būtų galima geriau suprasti ligą, nuspèti galimas gretutines patologijas ir ieškoti efektyviausio gydymo.

\section{Literatūra}

1. Mascialino B, Leinonen M, Meier T. Meta-analysis of the prevalence of Leber hereditary optic neuropathy mtDNA mutations in Europe. Eur J Ophthalmol 2012; 22(3): 461-5. https://doi.org/10.5301/ejo.5000055

2. Fraser JA, Biousse V, Newman NJ. The neuro-ophthalmology of mitochondrial disease. Surv Ophthalmol 2010;
55(4): 299-334. https://doi.org/10.1016/j.survophthal. 2009.10.002

3. Giraudet S, Lamirel C, Amati-Bonneau P, Reynier P, Bonneau D, Milea $\mathrm{D}$, et al. Never too old to harbour a young man's disease? Br J Ophthalmol 2011; 95(6): 887. https://doi.org/10.1136/bjo.2009.161539

4. Ohden KL, Tang PH, Lilley CC, Lee MS. Atypical Leber hereditary optic neuropathy. J Neuro-Ophthalmology 2016; 36(3): 304. https://doi.org/10.1097/WNO 0000000000000346

5. Riordan-Eva P, Sanders MD, Govan GG, Sweeney MG, Da Costa J, Harding AE. The clinical features of Leber's hereditary optic neuropathy defined by the presence of a pathogenic mitochondrial DNA mutation. Brain 1995; 118(2): 319-37. https://doi.org/10.1093/brain/118.2.319

6. Liu H, La Morgia C, Di Vito L, Nazarali S, Gauthier I, Syed M, et al. Differences in onset between eyes in patients with Leber's hereditary optic neuropathy (LHON). Acta Ophthalmol 2017; 95(S259). https://doi.org/10.1111/ j.1755-3768.2017.0T039

7. Yu-Wai-Man P, Griffiths PG, Hudson G, Chinnery PF. Inherited mitochondrial optic neuropathies. J Med Genet 2009; 46(3): 145-58. https://doi.org/10.1136/jmg.2007.054270

8. Savini G, Barboni P, Valentino M, Montagna P, Corteli P, Denegri A, et al. Retinal nerve fiber layer evaluation by optical coherence tomography in unaffected carriers with Leber's hereditary optic neuropathy mutations. Ophthalmology 2005; 112(1): 127-31. https://doi.org/10.1016/j.ophtha. 2004.09.033

9. Sadun AA, Salomao SR, Berezovsky A, Sadun F, Denegri AM, Quiros PA, et al. Subclinical carriers and conversions in Leber hereditary optic neuropathy: a prospective psychophysical study. Trans Am Ophthalmol Soc 2006; 104: 51-61.

10. Huoponen K. Leber hereditary optic neuropathy: clinical and molecular genetic findings. Neurogenetics 2001; 3(3): 119-25. https://doi.org/10.1007/s100480100115

11. Bi R, Zhang A-M, Yu D, Chen D, Yao Y-G. Screening the three LHON primary mutations in the general Chinese popu- 
lation by using an optimized multiplex allele-specific PCR. Clin Chim Acta 2010; 411(21-22): 1671-4. https://doi.org/ 10.1016/j.cca.2010.06.026

12. Tońska K, Kodroń A, Bartnik E. Genotype-phenotype correlations in Leber hereditary optic neuropathy. Biochim Biophys Acta 2010; 1797(6): 1119-23. https://doi.org/ 10.1016/j.bbabio.2010.02.032

13. Spruijt L, Kolbach DN, de Coo RF, Plomp AS, Bauer NJ, Smeets HJ, et al. Influence of mutation type on clinical expression of Leber hereditary optic neuropathy. Am J Ophthalmol 2006; 141(4): 676-676.e8. https://doi.org/ 10.1016/j.ajo.2005.11.007

14. Hudson G, Carelli V, Spruijt L, Gerards M, Mowbray C, Achilli A, et al. Clinical expression of Leber hereditary optic neuropathy is affected by the mitochondrial DNA-haplogroup background. Am J Hum Genet 2007; 81(2): 228-33. https://doi.org/10.1086/519394

15. Hung H-L, Kao L-Y, Huang C-C. Clinical features of Leber's hereditary optic neuropathy with the 11778 mitochondrial DNA mutation in Taiwanese patients. Chang Gung Med J 2003; 26(1): 41-7.

16. Harding AE, Sweeney MG, Miller DH, Mumford CJ, Kellar-Wood H, Menard D, et al. Occurrence of a multiple sclerosis-like illness in women who have a Leber's hereditary optic neuropathy mitochondrial DNA mutation. Brain 1992; 115(4): 979-89. https://doi.org/10.1093/brain/ 115.4.979

17. Hwang J-M, Chang BL, Park SS. Leber's hereditary optic neuropathy mutations in Korean patients with multiple sclerosis. Ophthalmologica 2001; 215(6): 398-400. https://doi.org/10.1159/000050896

18. Pfeffer G, Burke A, Yu-Wai-Man P, Compston DA, Chinnery PF. Clinical features of MS associated with Leber hereditary optic neuropathy mtDNA mutations. Neurology 2013; 81(24): 2073-81. https://doi.org/10.1212/01.wnl. 0000437308.22603 .43

19. Parry-Jones AR, Mitchell JD, Gunarwardena WJ, Shaunak S. Leber's hereditary optic neuropathy associated with multiple sclerosis: Harding's syndrome. Pract Neurol 2008; 8(2): 118-21. https://doi.org/10.1136/jnnp.2007.139360

20. Watanabe Y, Odaka M, Hirata K. [Case of Leber's hereditary optic neuropathy with mitochondrial DNA 11778 mutation exhibiting cerebellar ataxia, dilated cardiomyopathy and peripheral neuropathy]. Brain Nerve 2009; 61(3): 309-12.

21. Da Y, Zhang X, Li F, Yang X, Zhang X, Jia J. Posterior reversible encephalopathy syndrome in a Leber hereditary optic neuropathy patient with mitochondrial DNA $11778 \mathrm{G}>\mathrm{A}$ point mutation. J Neuro-Ophthalmology 2013; 33(3): 276-8. https://doi.org/10.1097/WNO.0b013e31828f8d75

22. Carelli V. Leber's hereditary optic neuropathy (LHON/11778) with myoclonus: report of two cases. J Neurol Neurosurg Psychiatry 2001; 71(6): 813-6. https://doi.org/10.1136/jnnp.71.6.813

23. Grazina MM, Diogo LM, Garcia PC, Silva ED, Garcia TD, Robalo CB, et al. Atypical presentation of Leber's hereditary optic neuropathy associated to mtDNA $11778 \mathrm{G}>\mathrm{A}$ point mutation - A case report. Eur J Paediatr Neurol 2007; 11(2): 115-8. https://doi.org/10.1016/j.ejpn.2006.11.015

24. Badura-Stronka M, Wawrocka A, Zawieja K, Silska S, Krawczyński MR. Severe manifestation of Leber's hereditary optic neuropathy due to $11778 \mathrm{G}>\mathrm{A}$ mtDNA mutation in a female with hypoestrogenism due to Perrault syndrome. Mitochondrion 2013; 13(6): 831-4. https://doi.org/10.1016/ j.mito.2013.05.011
25. Macmillan C, Kirkham T, Fu K, Allison V, Andermann E, Chitayat D, et al. Pedigree analysis of French Canadian families with T14484C Leber's hereditary optic neuropathy. Neurology 1998; 50(2): 417-22. https://doi.org/10.1212/WNL. 50.2.417

26. Montoya J, López-Gallardo E, Díez-Sánchez C, LópezPérez MJ, Ruiz-Pesini E. 20 years of human mtDNA pathologic point mutations: carefully reading the pathogenicity criteria. Biochim Biophys Acta Bioenerg 2009; 1787(5): 476-83. https://doi.org/10.1016/j.bbabio. 2008.09.003

27. Zhang J, Zhao F, Fu Q, Liang M, Tong Y, Liu X, et al. Mitochondrial haplotypes may modulate the phenotypic manifestation of the LHON-associated m.14484T $>$ C (MT-ND6) mutation in Chinese families. Mitochondrion 2013; 13(6): 772-81. https://doi.org/10.1016/j.mito.2013.05.002

28. Qu J, Zhou X, Zhao F, Liu X, Zhang M, Sun Y-H, et al. Low penetrance of Leber's hereditary optic neuropathy in ten Han Chinese families carrying the ND6 T11484C mutation. Biochim Biophys Acta 2010; 1800(3): 305-12. https://doi.org/10.1016/j.bbagen.2009.08.010

29. Sun Y-H, Wei Q-P, Zhou X, Qian Y, Zhou J, Lu F, et al. Leber's hereditary optic neuropathy is associated with the mitochondrial ND6 T14484C mutation in three Chinese families. Biochem Biophys Res Commun 2006; 347(1): 221-5. https://doi.org/10.1016/j.bbrc.2006.06.075

30. Ji Y, Zhang J, Yu J, Wang Y, Lu Y, Liang M, et al. Contribution of mitochondrial ND1 3394T $>C$ mutation to the phenotypic manifestation of Leber's hereditary optic neuropathy. Hum Mol Genet 2019; 28(9): 1515-29. https://doi.org/ $10.1093 / \mathrm{hmg} / \mathrm{ddy} 450$

31. Yang J, Zhu Y, Tong Y, Zhang Z, Chen L, Chen S, et al. The novel G10680A mutation is associated with complete penetrance of the LHON/T14484C family. Mitochondrion 2009; 9(4): 273-8. https://doi.org/10.1016/j.mito.2009.04.003

32. Wei Q-P, Zhou X, Yang L, Sun Y-H, Zhou J, Li G, et al. The coexistence of mitochondrial ND6 T14484C and 12S rRNA A1555G mutations in a Chinese family with Leber's hereditary optic neuropathy and hearing loss. Biochem Biophys Res Commun 2007; 357(4): 910-6. https://doi.org/10.1016/ j.bbrc. 2007.04.025

33. Brown MD, Trounce IA, Jun AS, Allen JC, Wallace DC. Functional analysis of lymphoblast and cybrid mitochondria containing the 3460,11778 , or 14484 Leber's hereditary optic neuropathy mitochondrial DNA mutation. J Biol Chem 2000; 275(51): 39831-6. https://doi.org/10.1074/jbc. M006476200

34. Lodi R. Phosphorus MR spectroscopy shows a tissue specific in vivo distribution of biochemical expression of the G3460A mutation in Leber's hereditary optic neuropathy. J Neurol Neurosurg Psychiatry 2002; 72(6): 805-7. https://doi.org/ 10.1136/jnnp.72.6.805

35. Nikoskelainen EK, Marttila RJ, Huoponen K, Juvonen V, Lamminen T, Sonninen P, et al. Leber's "plus": neurological abnormalities in patients with Leber's hereditary optic neuropathy. J Neurol Neurosurg Psychiatry 1995; 59(2): 160-4. https://doi.org/10.1136/jnnp.59.2.160

36. Lev D, Yanoov-Sharav M, Watemberg N, LeshinskySilver E, Lerman-Sagie T. White matter abnormalities in Leber's hereditary optic neuropathy due to the 3460 mitochondrial DNA mutation. Eur J Paediatr Neurol 2002; 6(2): 121-3. https://doi.org/10.1053/ejpn.2001.0558

37. Ronchi D, Cosi A, Tonduti D, Orcesi S, Bordoni A, Fortunato F, et al. Clinical and molecular features of an infant 
patient affected by Leigh Disease associated to $\mathrm{m} .14459 \mathrm{G}>\mathrm{A}$ mitochondrial DNA mutation: a case report. BMC Neurol 2011; 11(1): 85. https://doi.org/10.1186/1471-2377-11-85

38. Kim I-S, Ki C-S, Park K-J. Pediatric-onset dystonia associated with bilateral striatal necrosis and G14459A mutation in a Korean family: a case report. J Korean Med Sci 2010; 25(1): 180-4. https://doi.org/10.3346/jkms.2010.25.1.180

39. Gropman A, Chen T-J, Perng C-L, Krasnewich D, Chernoff E, Tifft C, et al. Variable clinical manifestation of homoplasmic G14459A mitochondrial DNA mutation. Am J Med Genet 2004; 124A(4): 377-82. https://doi.org/10.1002/ ajmg.a.20456

40. Funalot B, Reynier P, Vighetto A, Ranoux D, Bonnefont J-P, Godinot C, et al. Leigh-like encephalopathy complicating Leber's hereditary optic neuropathy. Ann Neurol 2002; 52(3): 374-7. https://doi.org/10.1002/ana.10299

41. Blakely EL, de Silva R, King A, Schwarzer V, Harrower T, Dawidek G, et al. LHON/MELAS overlap syndrome associated with a mitochondrial MTND1 gene mutation. Eur J Hum Genet 2005; 13(5): 623-7. https://doi.org/10.1038/sj.ejhg. 5201363

42. Srour M, Schwartzentruber J, Hamdan FF, Ospina LH, Patry L, Labuda D, et al. Mutations in C5ORF42 cause Joubert syndrome in the French Canadian population. Am J Hum Genet 2012; 90(4): 693-700. https://doi.org/10.1016/ j.ajhg.2012.02.011

43. Huang TL, Wang JK, Yoong Pang C, Kung Tsai R. Leber's hereditary optic neuropathy associated with the m.10197G >A mutation. J Clin Exp Ophthalmol 2017; 8(673): 4-8. https://doi.org/10.4172/2155-9570.1000673

44. Solyman O, MacIntosh P. Leber hereditary optic neuropathy in a mother and daughter associated with $\mathrm{m} .10197 \mathrm{G}>\mathrm{A} \mathrm{mu}-$ tation. J Neuro-Ophthalmology 2019; 39(1): 142. https://doi.org/10.1097/WNO.0000000000000714

45. Wang K, Takahashi Y, Gao Z-L, Wang G-X, Chen X-W, Goto J, et al. Mitochondrial ND3 as the novel causative gene for Leber hereditary optic neuropathy and dystonia. Neurogenetics 2009; 10(4): 337-45. https://doi.org/ 10.1007/s10048-009-0194-0

46. Ng YS, Lax NZ, Maddison P, Alston CL, Blakely EL, Hepplewhite PD, et al. MT-ND5 mutation exhibits highly variable neurological manifestations at low mutant load EBioMedicine 2018; 30: 86-93. https://doi.org/10.1016/ j.ebiom.2018.02.010

47. Hinttala R, Kervinen M, Uusimaa J, Maliniemi P, Finnilä S, Rantala $\mathrm{H}$, et al. Analysis of functional consequences of haplogroup J polymorphisms m.4216T $>\mathrm{C}$ and $\mathrm{m} .3866 \mathrm{~T}>\mathrm{C}$ in human MT-ND1: mutagenesis of homologous positions in Escherichia coli. Mitochondrion 2010; 10(4): 358-61. https://doi.org/10.1016/j.mito.2010.02.002

48. Liu Y, Zhuang S-L, Tong Y, Qu J, Zhou X-T, Zhao F-X. Leber's hereditary optic neuropathy and limbs abnormity claudication may be associated with the mitochondrial ND1 T3866C mutation. Hered 2010; 32(2): 141-7. https://doi.org/10.3724/SP.J.1005.2010.00141

49. Widgren P, Hurme A, Falck A, Keski-Filppula R, Remes AM, Moilanen J, et al. Genetic aetiology of ophthalmological manifestations in children - a focus on mitochondrial disease-related symptoms. Acta Ophthalmol 2016; 94(1): 83-91. https://doi.org/10.1111/aos.12897

50. Zhou X, Qian Y, Zhang J, Tong Y, Jiang P, Liang M, et al. Leber's hereditary optic neuropathy is associated with the T3866C mutation in mitochondrial ND1 gene in three Han
Chinese families. Investig Opthalmology Vis Sci 2012; 53(8): 4586-94. https://doi.org/10.1167/iovs.11-9109

51. Leo-Kottler B, Luberichs J, Besch D, Christ-Adler M, Fauser S. Leber's hereditary optic neuropathy: clinical and molecular genetic results in a patient with a point mutation at $\mathrm{np}$ T11253C (isoleucine to threonine) in the ND4 gene and spontaneous recovery. Graefe's Arch Clin Exp Ophthalmol 2002; 240(9): 758-64. https://doi.org/10.1007/s00417002-0494-7

52. Kösel S, Grasbon-Frodl EM, Mautsch U, Egensperger R, von Eitzen U, Frishman D, et al. Novel mutations of mitochondrial complex I in pathologically proven Parkinson disease. Neurogenetics 1998; 1(3): 197-204. https://doi.org/ $10.1007 / \mathrm{s} 100480050029$

53. Tonska K, Kurzawa M, Ambroziak AM, Korwin-Rujna M, Szaflik JP, Grabowska E, et al. A family with $3460 \mathrm{G}>\mathrm{A}$ and $11778 \mathrm{G}>\mathrm{A}$ mutations and haplogroup analysis of Polish Leber hereditary optic neuropathy patients. Mitochondrion 2008; 8(5-6): 383-8. https://doi.org/10.1016/j.mito. 2008.08.002

54. Catarino CB, Ahting U, Gusic M, Iuso A, Repp B, Peters K, et al. Characterization of a Leber's hereditary optic neuropathy (LHON) family harboring two primary LHON mutations m.11778G $>$ A and m.14484T $>C$ of the mitochondrial DNA Mitochondrion 2017; 36: 15-20. https://doi.org/10.1016/ j.mito.2016.10.002

55. Jiang P, Liang M, Zhang C, Zhao X, He Q, Cui L, et al. Biochemical evidence for a mitochondrial genetic modifier in the phenotypic manifestation of Leber's hereditary optic neuropathy-associated mitochondrial DNA mutation. Hum Mol Genet 2016; 25(16): 3613-25. https://doi.org/10.1093/ hmg/ddw199

56. Nakaso K, Adachi Y, Fusayasu E, Doi K, Imamura K, Yasui K, et al. Leber's hereditary optic neuropathy with olivocerebellar degeneration due to G11778A and T3394C mutations in the mitochondrial DNA. J Clin Neurol 2012; 8(3): 230-4. https://doi.org/10.3988/jcn.2012.8.3.230

\section{Matukynaitė, R. Liutkevičienė, A. Gelžinis, R. Žemaitienè}

\section{GENOTYPE AND PHENOTYPE ASSOCIATION IN LEBER'S HEREDITARY OPTIC NEUROPATHY}

\section{Summary}

Leber's hereditary optic neuropathy (LHON) is one of the most common hereditary mitochondrial optic neuropathies characterized by bilateral, painless, subacute or acute loss of central vision. The disease usually develops between the ages of 15 and 35 . The majority of LHON patients are men (about 90\%). LHON prevalence is commonly associated with the three most common point mutations in the mitochondrial deoxyribonucleic acid (mtDNA) m.11778 G>A, m.14484 T>C, m.3460 G>A. Point mutations that occur in deoxyribonucleic acid leads to mitochondrial respiratory chain I complex damage in all main known mutations.

In this article, we review associations between the genotype and phenotype of LHON with the various mtDNA mutations in patients with LHON.

Keywords: Leber's hereditary optic neuropathy, genotype, phenotype, associations.

Gauta:

20200504

Priimta spaudai: 20200624 